\title{
OM LÄTTJA* OCH PROFESSIONALISM
}

Minns en moralitet från en av folkskolans morgonböner. Den handlade om en spindel som, efter att ha fullbordat sitt nät, beundrade resultatet som glittrade i morgonsolen. Men plötsligt fick den syn på en tråd i kanten som störde helhetens symmetri, bet av(?) den - och hela nätet rasade samman. Spindeln hade glömt att det var själva utgångstråden han sett, den som varit grunden för hela bygget.

I kulturinstitutionernas egenliv blir gärna den professionella specialiseringen ledande honnörsord, apparaternas finslipade fulländning kulturarbetarnas stolthet. Lätt kan en annan sorts professionalism bli åsidosatt, mål-medvetenheten, det kommunikativa uppdrag som en gång gav institutionen samhälleligt berättigande.

Alpha Oumar Konaré, president i ICOM 1988-91, därefter president i västafrikanska republiken Mali, framhöll vid ett stockholmsbesök i augusti kulturverksamhetens betydelse som riktningsgivare i ett samhälles liv och utveckling. Men varnade samtidigt för den intellektuella lättjan och passiviteten bland kulturarbetare som nöjde sig med att förvalta sina institutioners etablerade rutinverksamheter, vars förutsättningar försvunnit eller förändrats. Där finns ett hot som är särskilt påtagligt i de traditionellt bakåtblickande museerna.

Det kan finnas fog för det uttalande om museerna som med statsmannamässig retorik mötte i den svenska regeringsförklaringen efter höstens allmänna val:

Museernas roll för att bevara och utveckla ett tolerant och demokratiskt sambälle görs tydligare. Och med en mer generell formulering hette det:

Kulturen är samtidens känselspröt in i framtiden. Här blandas historiens identitet med forhoppningarnas nyfikenhet.

Kanske kan dessa politiska kursiveringar uppmuntra museerna till att utveckla sin närvaro i samhället. Den kan just nu uppstå i de integrativa tendenser som närmar bibliotek, arkiv och museer till varandra i försök att med gemensamma resurser skapa verklighetsnära helhetsbilder, där primärdata ur samhällets samlade minneslager med datateknikens hjälp sammanförs så att enskilda människor kan 
söka fram sitt eget konkreta förflutna. Här ges förutsättningarna för en genuint demokratisk historieskrivning. Dessa förändrade förutsättningar för berättande skärper också utmaningen till museerna att på ett nyskapande sätt utveckla sina mediespecifika förmedlingsformer.

Viktigt är också att den stärks i utställningssamverkan t.ex. det gemensamma projektet Framtidstro i svenska museer, som tydligt situerar museerna i nutiden. Eller genom deltagande i nätverk som ger impulser och näring till förnyelse - exempelvis SAMPs strävan att upprätta likvärdiga tvillingskap mellan svenska och afrikanska museer för ett reellt kulturutbyte.

Numrets fyra första bidrag - Federspiels, MacDonalds, Mordhorsts och Hansens härrör just från ett nytt nätverk, det för museologiskt idéutbyte, skapat av Jette Sandahl vid Nationalmuseet i Köpenhamn. Fler texter som tillkommit i nätverket är att vänta!

Slumpvisa, imaginära samtal uppstår då och då mellan bidragen i samma eller skilda nummer av tidskriften. Sålunda kan det vara givande att i föreliggande nummer läsa Per Råbergs text om kulturpolitik och värdekultur i ljuset av utsagorna här ovan. Beate Federspiels text är explicit ett svar på Kenneth Hudsons och Torben Witts diskussion omkring kulturarvsbegreppet i förra numret. Hon hänvisar vidare till samma text (Our Creative Diversity) som Råberg behandlar från en annan utgångspunkt. Till temat anknyter Ivo Maroevic med sin teoretiska analys.

Juhani Kostets uppfordran till eftertanke omkring insamlingsproblematiken i förra numret får en sorts dubbelbelysning av Maiken Hansen och Tammerforskollegorna Ritva Palo-oja och Leena Willberg. Mytte Fentz och Ulla Wagner fördjupar båda analysen av den etnografiska förståelse- och förmedlingsproblematik som skymtat tidigare i Nordisk Museologi.

Med dessa och ytterligare ett par bidrag avslutar tidskriften sin sjätte årgång och hoppas på återseende år 1999 med en läsekrets i glädjande tillväxt!

$$
\text { Per-Uno Agren }
$$

\footnotetext{
* Det svenska lättja avvisas (med förtrytelse) av no/da redaktörer som samnordiskt ord. Motsvaras i no/da av la(d)tska(b)p, dovenska(b)p. Konaré använde sannolikt franskans paresse, i simultanengelska laziness.
} 